\title{
BUSH LAWYERS IN NEW SOUTH WALES AND QUEENSLAND: A SPATIAL ANALYSIS
}

\author{
KEVIN MCDOUgALL* \\ REID MORTENSEN**
}

This article deals with the effect that different structures for the legal profession might have on supporting legal practice. There is a particular focus on Queensland, and its Law Society's claim that conveyancing protection is important infrastructure for practice in the bush. A spatial analysis was undertaken to compare the availability of legal services in Queensland and New South Wales (where non-lawyer conveyancing is allowed) in 2008. Areas in the two states classified according to the Accessibility/Remoteness Index of Australia (ARIA) were compared, and it was found that NSW had an equal or marginally better provision of legal services in all ARIA categories. The implications that this has for conveyancing protection, and other differences between the states (the earlier availability of incorporated law practices (ILPS) and the higher number of regional law schools in NSW) are discussed. Only a comprehensive longitudinal analysis can more strongly isolate the likely effect, if any, of conveyancing protection, ILPs and regional law schools on bush practice. However, the suggestion is that the differences in legal infrastructure - including conveyancing protection - are less important for supporting legal services in the bush than social considerations (family, lifestyle, professional development, gender, employment patterns and salary) are likely to be.

\footnotetext{
* Associate Professor of Surveying and Spatial Science, University of Southern Queensland, Toowoomba, Australia.

** Professor of Law, University of Southern Queensland, Toowoomba, Australia. The authors recognise the support given by the Queensland Legal Practitioners Interest on Trust Accounts Fund for the research and writing of this article, and for other work involving the effect of the reservation of conveyancing work to solicitors in Queensland. The Law Society of New South Wales and the Queensland Legal Services Commissioner are thanked for providing the data that enabled this spatial analysis to be undertaken. We also wish to thank Associate Professor Geoff Cockfield for his assistance, and Dev Raj Paudyal and Kathy Glynn for research support in the preparation of this article.
} 


\section{INTRODUCTION}

\section{A The Bush Lawyer Crisis}

The Law Council of Australia's 2009 Report into the Rural, Regional and Remote Areas reached general conclusions that there is a shortage of lawyers in regional, rural and remote areas of Australia, and that, with the likely retirement of lawyers in these areas over the next five to ten years, the shortage will become more acute. ${ }^{1}$ As close to half of the potentially retiring lawyers are sole practitioners, without there being anyone to replace them in their own communities, law practices could disappear completely from many communities in 'the bush'. ${ }^{2}$ The Law Council noted that this had serious implications for access to justice. 'Bush lawyers' - solicitors practising in regional, rural and remote areas of Australia ${ }^{3}$ - carried higher levels of legal aid work than metropolitan lawyers did, undertook significant levels of pro bono work, and made extensive unpaid contributions to community services and activities. ${ }^{4}$ The Council's concerns about the increasing metrocentrism of Australian legal professions are not, therefore, just about the interests of lawyers. They go to the heart of all citizens' access to law, and the importance of skilled professionals to the life of all communities. However, the purpose of the Rural, Regional and Remote Areas Report was to identify a problem, not to give solutions. In similar work for the Northern Rivers Community Legal Centre, Trish Mundy did propose solutions, largely to improve recruitment of lawyers (and hopefully then to improve their retention) through public funding, indirect subsidies and earlier regional work placement of law students and graduates. ${ }^{5}$

\footnotetext{
${ }^{1}$ Law Council of Australia and Law Institute of Victoria, 'Report into the Rural, Regional and Remote Areas Lawyers Survey' (July 2009) 21 <http://www.lawcouncil.asn.au/ programs/national-policy/recruitment_retention/rrr.cfm>.

${ }^{2}$ Ibid.

${ }^{3}$ The 'bush lawyer' is better known colloquially as a 'layman who fancies he has a knowledge of law' (OED), but is also often used in Australian literature and professional circles to refer to the qualified lawyer in the bush. See eg, Norman Verschuer Wallace, Bush Lawyer (Rigby, 1976); R Guides, 'Bushman Lawyer' (1995) 15(3) Proctor 6; Julie Lewis, 'When the Rain Won't Come' (2007) 45(10) Law Society Journal 26.

${ }^{4}$ Law Council of Australia and Law Institute of Victoria, above n 1, 5-6.

${ }^{5}$ Trish Mundy, 'Recruitment and Retention of Lawyers in Rural, Regional and Remote NSW' (Literature Review, Northern Rivers Community Legal Centre, July 2008) 21 $<$ http://www.nrclc.org.au/SiteMedia/w3svc728/Uploads/Documents/RecruitmentRetentionOf Lawyers.pdf>; Trish Mundy, 'Recruiting and Retaining Lawyers: A Problem in Rural, Regional and Remote Communities' (2009) 34(1) Alternative Law Journal 32, 47.
} 
This research is differently positioned. Aspects of Mundy's research are taken into account, but we are also addressing questions of 'legal infrastructure'. At the same time as there have been increasing concerns about reduced proportions of bush lawyers, Australian legal professions have been undergoing continuing regulatory reform. From the mid-1990s to 2006, the Standing Committee of Attorneys-General (SCAG), with the support of the Law Council, was developing the Model Laws on national legal practice, and regulations and rules beneath them. ${ }^{6}$ The Model Laws have been taken up in almost every Australian jurisdiction, but further reform is now being considered. The National Legal Profession Reform project, again sponsored by SCAG with Law Council support, aims to achieve some centralisation of legal profession regulation and to reduce regulatory requirements for multijurisdiction practices. ${ }^{7}$ But, although some regional law practices might expect collateral benefits from reforms that affect multi-jurisdiction practices, ${ }^{8}$ almost nothing in the latest wave of legal profession reform has openly aspired to improve the legal infrastructure for bush lawyers. Here, by considering the effect that different structures for the regulation of the profession might have, we hope gradually to develop understanding of what legal infrastructure, if any, could help to support regional, rural and remote area practice, and therefore to maintain or improve access to law in the Australian bush.

The focus is on the infrastructure for bush lawyers in Queensland. The Rural, Regional and Remote Areas Report noted that Queensland, South Australia and the Northern Territory were the jurisdictions where the shortage of lawyers in the bush was most acute. ${ }^{9}$ Queensland is easily the most populous of the three and, therefore, the state where any shortage of bush lawyers would have the most extensive, negative social effects. ${ }^{10}$ In our consideration of the availability of legal services in regional, rural and remote areas, the density of solicitors and law practices in Queensland is compared with the

\footnotetext{
${ }^{6}$ Standing Committee of Attorneys-General, Legal Profession - Model Laws Project: Model Bill (Model Provisions) (2 ${ }^{\text {nd }}$ ed, 2006).

${ }^{7}$ National Legal Profession Reform Taskforce, 'Legal Profession National Law' (Consultation Draft, 14 May 2010) <http://www.ipc.nsw.gov.au/lawlink/Corporate/ll_corporate.nsf /pages/lpr_documentlibrary>; National Legal Profession Reform Taskforce, 'Legal Profession National Rules' (Consultation Draft, 14 May 2010) <http://www.ipc.nsw.gov.au/lawlink /Corporate/11_corporate.nsf/pages/lpr_documentlibrary>.

${ }^{8}$ See Albury and District Law Society and North East Law Association, Concerns for CrossBorder Legal Practitioner: Submission on National Legal Profession Reform, 2010 $<216+$ ALDS+and+NELA+Submission+NLPR+130810-2.doc $>$.

${ }^{9}$ Law Council of Australia and Law Institute of Victoria, above n 1, 21.

${ }^{10}$ The 2006 Census reports the population of Queensland at 3.9 million, South Australia at 1.5 million, and the Northern Territory at 193000.
} 
density of solicitors and law practices in New South Wales. The comparison with New South Wales is made because the states are adjacent and, a related factor, New South Wales is the closest state to Queensland in geodemographic profile. ${ }^{11}$ Furthermore, there are differences between New South Wales and Queensland in the legal infrastructure claimed to be necessary to help sustain law practices. In particular, the competition-based reforms made to the legal profession from the 1980s were, to some extent, undertaken in New South Wales before they were undertaken in Queensland. And, while since 2007 the supporting legal infrastructure for the regulation of lawyers in both states is almost identical, there remains one significant difference between solicitors' professions in the two states and which, in Queensland, is claimed to be of significance for practice in the bush - conveyancing protection.

\section{B The Conveyancing Claim}

In Australia, it is now only Queensland and the Australian Capital Territory that reserve conveyancing work exclusively for lawyers. In every other Australian jurisdiction, conveyancing can be lawfully conducted by licensed non-lawyer conveyancers, regulated to differing degrees by state or territory legislation. In New South Wales, access to the market for conveyancing services was extended beyond the legal profession in $1993^{12}$ and, now, is regulated by the Conveyancers Licensing Act 2003 (NSW). In Queensland, that access is still forbidden by the exclusive reservation of 'legal practice' (which includes conveyancing work) ${ }^{13}$ to Australian lawyers who hold the equivalent of a Queensland solicitor's practising certificate. ${ }^{14}$ The only inroad into this reservation is for real estate agents involved in the creation of land

\footnotetext{
${ }^{11}$ This follows from the use of the Accessibility/Remoteness Index of Australia (ARIA). See below nn 50-66 and associated text. New South Wales is used as the comparator jurisdiction for Queensland because it is the closest approximation in terms of both decentralised urban settlement and in having remote and very remote regions. No postcode district in the Australian Capital Territory or Victoria is considered remote in any degree, and none in Tasmania is considered very remote. Higher proportions of the geographic areas of the Northern Territory, South Australia and Western Australia are considered very remote. These jurisdictions lack the intensity of settlement that Queensland and New South Wales have in areas classified as accessible, moderately accessible or remote; all areas in those ARIA classifications are also in closer proximity to the capital city than is the case in New South Wales and Queensland.

${ }^{12}$ Conveyancers Licensing Act 1992 (NSW).

${ }^{13}$ Queensland Law Society Inc v Sande (No 2) [1998] 1 Qd R 273.

${ }^{14}$ Legal Profession Act 2007 (Qld) s 24(1).
} 
sale contracts. ${ }^{15}$ The parallel reservation of 'legal practice' in the Legal Profession Act 2004 (NSW) has an exception for licensed conveyancers. ${ }^{16}$

The non-lawyer conveyancer is not a modern innovation. New South Wales (including the parts that became Victoria and Queensland) introduced courtadmitted conveyancers in the Attorneys' Bills and Conveyancing Act 1847. Admissions of these 'certificated conveyancers' were only abandoned in Victoria in $1915,{ }^{17}$ New South Wales in $1935,{ }^{18}$ and Queensland in 1940. ${ }^{19}$ And the last non-lawyer conveyancer to hold a practising certificate in Queensland did so in $1987 .{ }^{20}$

Through the 2000s, the Queensland government has continued to defend the policy of reserving conveyancing work exclusively for solicitors. However, in the last National Competition Council review of the 'legal practice' barrier to entering Queensland conveyancing markets, the government limited its justifications for conveyancing protection to 1) the existing competitiveness of the market (despite services being supplied only by solicitors) and 2) the fact that there was no evidence that it was possible to deliver cost-efficient regulation of non-lawyer conveyancers alongside adequate consumer protection. ${ }^{21}$ The government has not offered the range of other arguments that the Queensland Law Society has pressed in its position that the state should not reactivate non-lawyer conveyancing. Prominent among these other

\footnotetext{
${ }^{15}$ Ibid s 24(2)(e).

${ }^{16}$ Legal Profession Act 2004 (NSW) s 14(2)(e). This is not to say that the reintroduction of non-lawyer conveyancing in New South Wales was uncontroversial. It was said in the 1980s that it would be a 'perverse' development: J M Bennett, A History of Solicitors in New South Wales (Legal Books, 1984) 341. Even after non-lawyer conveyancing was introduced in 1993, New South Wales solicitors were being advised, when dealing with licensed conveyancers, to take precautions that were not usual when dealing with solicitors in conveyancing, and so make dealings more difficult for the conveyancers: 'Solicitors May Have Duty to Confirm Status of Conveyancers' (1994) 32(2) Law Society Journal 11. Representations continued to be made not to expand the permissible scope of non-lawyer conveyancers' work: 'Limitations Should Continue on Work of Licensed Conveyancers, Law Society Tells Premier' (1995) 33(8) Law Society Journal 69.

${ }^{17}$ Legal Profession Practice Act 1915 (Vic) s 24.

${ }^{18}$ Legal Practitioners Amendment Act 1935 (NSW) s 8(c); Legal Practitioners Act 1898 (NSW) s 20A(1).

${ }^{19}$ Legal Practitioners Act Amendment Act 1938 (Qld) s 2.

${ }^{20}$ According to Sande and Registrar Supreme Court of Queensland [1995] AATA 593, [39] and Sande v Registrar Supreme Court of Queensland (1996) 134 ALR 560, 571 a Mr Garde, who was admitted as a conveyancer in 1935, took a conveyancer's certificate in 1987.

${ }^{21}$ National Competition Council, 'Assessment of Governments' Progress in Implementing the National Competition Policy and Related Reforms: 2005' (October 2005) 13.8 $<$ http://ncp.ncc.gov.au/docs/2005\%20assessment.pdf $>$.
} 
arguments has been the need to support the bush lawyer. The Queensland Law Society has regularly appealed to the importance of the conveyancing reservation for regional, rural and remote area law practices, and the crosssubsidy it purportedly provides for other legal services in the bush.

In one of the earliest arguments in Queensland about the introduction of nonlawyer conveyancing, the government actually suggested that, if more conveyancing services were needed anywhere, they were needed in the regions. This was a curious point, as there were already court-admitted nonlawyer conveyancers in the colony. But in the parliamentary debates in 1877 over amendments to the Torrens legislation that would have included the introduction of South Australian-style land brokers to Queensland, Charles Mein, the Postmaster-General and a solicitor, suggested that brokers could possibly help to overcome the shortage of conveyancing services in 'the interior'. ${ }^{22}$ That view was not expressed again. Through the late $19^{\text {th }}$ and into the mid $20^{\text {th }}$ centuries, regional solicitors (more so than their Brisbane counterparts) strongly urged prosecutions of real estate agents and provincial bank managers for illegal conveyancing. They also expressed concern about the lawful conveyancing being offered at cut-price rates by the Public Curator. ${ }^{23}$

The conveyancing reservation began to look precarious as reform of the Queensland legal profession loomed in the late 1990s and early 2000s, and as barriers to entering conveyancing markets were lowered in other states and the Northern Territory. In its submissions on professional reform, the Queensland Law Society consistently pressed for the reservation to be maintained and, as one of its arguments, appealed to the support needed for bush lawyers. It argued 'that licensing conveyancers may disadvantage regional and country practices and result in their being deprived of young lawyers to whom regional and country practice will as a result be less attractive. ${ }^{24}$ The government did not accept the point, but parliamentarians from regional Queensland were presumably voicing representations of solicitors in their electorates when they suggested that the reservation was

22 Queensland, Parliamentary Debates, Legislative Council, 31 May 1877, 248, 255 (Charles Mein); see also Gordon Sandeman at 251.

${ }^{23}$ Helen Gregory, The Queensland Law Society Inc 1928-1988: A History (Queensland Law Society, 1991) 40, 61, 114-16.

${ }^{24}$ The Queensland Law Society did not publish its submissions on professional reform, so they must be gleaned from the government reports. See Queensland, Legal Profession Reform, Green Paper (1999) 26; Queensland, National Competition Policy Review - Regulation of Legal Profession, Issues Paper (2001) 20. The Queensland Law Society's submission in the National Competition Policy Review was that '[i]f conveyancers are allowed to practise, rural and regional practices will close': at 20. 
important for maintaining the viability of regional law practices. ${ }^{25}$ Three recent Queensland Law Society Presidents have continued this argument. In 2002, Joe Tooma said that 'diluting the conveyancing market with private practitioners would impact on the viability of some law firms, especially in the bush. We do not want to see rural areas lose their legal services. ${ }^{26}$ In 2003, Glenn Ferguson claimed that 'conveyancing was the backbone of the practice of many regional solicitors' and that most 'of the solicitors in regional centres are generally the only solicitor in that town'. ${ }^{27}$ In 2008, responding to the emergence of non-lawyer conveyancing companies taking the form of Incorporated Legal Practices (ILPs) with a single solicitordirector, Megan Mahon said:

... solicitors in regional centres were more likely to be affected by competition from conveyancers than practices in Brisbane. Regionally, I imagine this will have an effect. But it will depend on whether conveyancers want to go to the regions. ${ }^{28}$

The purpose of this research is not to develop a case for relaxing the barrier to entering Queensland conveyancing markets that is currently the exclusive province of solicitors' practices. Indeed, in related research, Byrne and Mortensen concluded that other competition-based reforms have probably brought Queensland conveyancing markets to the point where the costs of introducing and regulating non-lawyer conveyancing may well exceed any benefit it could bring to consumers - a benefit that is likely to be minimal. The introduction in mid-2007 of ILPs, by which profits from conveyancing in Queensland can now be streamed directly to people other than lawyers, seems to have brought the market to a point where consumers enjoy the most costefficient, protective regulatory environment without the burden of a new licensing regime. ${ }^{29}$

25 Queensland, Parliamentary Debates, Legislative Assembly, 26 November 2003, 5238 (Lawrence Springborg); Queensland, Parliamentary Debates, Legislative Assembly, 27 November 2003, 5299 (Bill Flynn).

${ }^{26}$ Chris Griffith, 'Lawyers May Keep Property Monopoly', Courier Mail (Brisbane) 5 June 2006, 12.

${ }^{27}$ C Merritt, 'Conveyancing Market "Too Tough”, Australian Financial Review, 12 September 2003.

${ }^{28}$ Chris Merritt, 'Conveyancers Find Way to Break the Land Law Monopoly', The Australian (Sydney), 29 August 2008.

${ }^{29}$ Mark Byrne and Reid Mortensen, 'The Queensland Solicitors' Conveyancing Reservation: Past and Future Development - Part I' (2009) 28(2) University of Queensland Law Journal 252 ('Conveyancing Reservation I'); Mark Byrne and Reid Mortensen, 'The Queensland Solicitors' Conveyancing Reservation: Past and Future Development - Part II', (2010) 29(2) University of Queensland Law Journal 245 ('Conveyancing Reservation II'). 
However, the validity of the bush lawyers argument for conveyancing protection in particular is worth closer consideration for a number of reasons. First, the Queensland Law Society seriously presents the conveyancing reservation as important legal infrastructure for supporting bush practice. If there is any validity to the argument, then conveyancing protection would also demand some consideration in other parts of Australia as a means of stemming the loss of solicitors from the bush, and therefore of giving Australians in regional, rural and remote areas reasonable access to law. ${ }^{30}$ Secondly, it cannot simply be assumed that the removal of protectionist measures (such as a barrier to entering conveyancing markets) is necessarily detrimental to the businesses or practices that they protect. Important economic assessments suggest that dismantling protection, in the longer term, can sometimes help formerly protected businesses to flourish. ${ }^{31}$ The Productivity Commission has nevertheless also recognised that competitionbased reforms can have negative as well as positive impacts on regional and remote communities. ${ }^{32}$ There is some anecdotal evidence that conveyancing work has declined in law practices in states that have opened markets to nonlawyer conveyancers since the $1990 \mathrm{~s},{ }^{33}$ but that this may have been offset by increased volumes of business in other areas such as commercial, financial and corporate work. ${ }^{34}$ However, there is no evidence of whether this offset is sufficient to retain similar levels of viability for legal practice in regional and remote areas of those states, and so whether or not those states have degraded the conditions needed for maintaining legal services in the bush.

Thirdly, an initial intuitive response is that the bush lawyers argument seems improbable. Contrary to this argument, it would appear more likely that nonlawyer conveyancers would have greater interest in gaining access to metropolitan property markets than those in the regions. The business of the non-lawyer conveyancer lacks the diversity of legal practice, and therefore

\footnotetext{
${ }^{30}$ In 1992, Grant made the bush lawyers argument against the reintroduction of non-lawyer conveyancing in New South Wales. He implicitly claimed that the long-term prevalence of land broking in South Australia was the reason for the paucity of regional solicitors in that state: David Grant, 'The Country Solicitor' (1992) 66 Australian Law Journal 453, 453-4.

${ }^{31}$ See, eg, Productivity Commission, 'Review of Australia's General Tariff Arrangements' (Inquiry Report No 12, 22 July 2000) 55 <http://www.pc.gov.au/_data/ assets/pdf_file/0012/31170/tariff.pdf>; Productivity Commission, 'Review of TCF Assistance' (Inquiry Report No 26, 31 July 2003) 41 <http://www.pc.gov.au/_ data/assets/pdf_file/0020/26822/tcf.pdf $>$.

${ }^{32}$ Productivity Commission, 'Impact of Competition Policy Reforms on Rural and Regional Australia' (Inquiry Report No 8, 8 September 1999) $371<\mathrm{http} / / / w w w . p c . g o v . a u /$ data /assets/pdf_file/0003/32439/compol.pdf\$.

${ }^{33}$ Ainslie Lamb and John Littrich, Lawyers in Australia (Federation Press, 2007) 111.

${ }^{34}$ Ibid 111-113.
} 
requires a larger property market and a higher turnover of landholding to be viable. True to this impression, the efforts of non-lawyer conveyancers to gain access to Queensland conveyancing markets have been devoted exclusively to the urbanised south-east corner, with a particular focus on the Gold Coast. ${ }^{35}$ As Megan Mahon came close to conceding, ${ }^{36}$ the bush seems to be of less interest to them. Still, even if this impression is true, we do not wish to understate the effect that lowering barriers to entering conveyancing markets might have on regional and remote legal practice. Although Law Society Presidents may have been exaggerating the interest that non-lawyer conveyancers have in the bush, it has been shown that the mere threat or possibility of non-lawyer conveyancing can see temporary price-cutting by solicitors - with all of the implications that that has on law practice revenue, the viability of the practice, and any cross-subsidisation of other legal services (if that happens). ${ }^{37}$

The bush lawyers argument therefore merits careful empirical analysis. For the Queensland Law Society's claims are, at present, just that. They have only been asserted; no evidence has ever been mustered to support them. The Law Council did report that 60 per cent of Australian regional, rural and remote area law practices that responded to its survey did conveyancing work. ${ }^{38}$ However, that information is reported at the most superficial level. Just how important conveyancing was as a revenue stream, how profitable the work was, or the extent to which other areas of practice were independently profitable (and whether they were therefore in need of cross-subsidies) are not identified. It is also not clear whether there is greater reliance on conveyancing work in bush practices than in metropolitan practices, whether there are any differences in the significance of conveyancing to law practices in different states and territories, and whether there are any differences in the significance of conveyancing to law practices in different regions of any given state or territory. Further, none of this shows the importance of conveyancing protection for bush practice - which is the question in Queensland - as compared with conveyancing revenue, which may be a very different thing.

\footnotetext{
${ }^{35}$ Conveyancing Reservation I, above n 29, 261-2.

${ }^{36}$ Merritt, above $\mathrm{n} 28$.

37 From studies on the effect between 1985 and 1992 of reintroducing non-lawyer conveyancing in England and Wales: F H Stephen and J H Love, 'Regulation of the Legal Profession' in Boudewijn Bouckaert and Gerrit de Geest (eds), Encyclopedia of Law and Economics (Edward Elgar, 1999) vol 3, 987, 995-6.

${ }^{38}$ Law Council of Australia and Law Institute of Victoria, above n 1, 9-10. This is reported as the solicitors' 'practice area', but a practice area was any one of a number of areas in which they 'mainly' practised: at 25 . The areas of wills and probate ( 66 per cent) and commercial law (60 per cent) were either more common than conveyancing, or as common as conveyancing as practice areas. Family law (57 per cent) was close: at 10.
} 
Our research tries to address the claims of conveyancing and bush lawyers. However, it can initially only reach modest conclusions. It rests on the different legal barriers to entering conveyancing markets in New South Wales and Queensland. If these different barriers have any propensity to affect the availability of legal services in either state, they have now had considerable time to do so. The availability of non-lawyer conveyancing in New South Wales (since 1993) and its effective exclusion in Queensland (since 1987 at latest) enable a comparison of the availability of legal services in the two states and, therefore, enable some assessment to be made of the effect that non-lawyer conveyancing might have on that availability. However, for any meaningful inferences to be drawn from a comparison of regional and remote area legal services in the two states, it is also important to compare the availability of services in one kind of community in each state with similar communities in the other. To that end, a spatial analysis of law practices and solicitors must be undertaken.

\section{A Spatial Analysis of Legal Services}

\section{A The Nature of Spatial Analyses}

In recent years, it has become reasonably common to see the regular use of geographic or spatial information in research on a range of social issues. The easy availability of Google Earth, Google Maps, Microsoft Virtual Earth and in-car Global Positioning Systems (GPS) suggests the importance that spatial information has acquired for personal or social use. ${ }^{39}$ Even in the 1980 s, it was estimated that approximately 70-80 per cent of government decisions had a geographic or spatial dimension, ${ }^{40}$ particularly in areas such as local or regional planning, land development, and planning for services or infrastructure.

Spatial information has emerged from traditional cartographic and mapping representations that have gradually been transformed from paper-based maps

\footnotetext{
${ }^{39}$ Perhaps one of the most significant and visible social impacts of spatial information occurred upon the release of Google Earth to the public in June 2005. The release of Google Earth caused an enormous increase in media attention on digital globes and a new awareness of the power of geographic information. Other common spatial portals such as Google Maps and Microsoft Virtual Earth are now used for a multitude of applications - from locating businesses to investigating holiday destinations. In-car navigation systems (which have been taken up by over 25 per cent of Australian drivers) rely on spatial information in the form of street networks and points of interest.

${ }^{40}$ Rebecca Somers, 'Geographic Information Systems in Local Government: A Commentary' (1987) 53(10) Photogrammetric Engineering and Remote Sensing 1379.
} 
and plans of all shapes and sizes to digital mapping products. Government and business are now significantly reliant on spatial information products and systems. These spatial products are increasingly integrated into information systems as part of governmental or business tools. Geographic Information Systems (GIS) are powerful software systems that can integrate and analyse various forms of spatial and non-spatial information. The resulting outputs from a GIS can be in the form of maps, reports or analyses that assist government and business decisions, and often provide new perspectives on issues or problems.

\section{B Information and Data on Law Practices}

\section{$1 \quad$ Law Practice and Solicitor Data}

For this research, the Law Society of New South Wales and the Queensland Legal Services Commissioner provided information on the location of law practices (meaning sole solicitors, partnerships of solicitors, ILPs or MultiDisciplinary Partnerships) ${ }^{41}$ in each state as of 1 July 2008. The relevant data extracted from this information were the street or postal address of the law practice, and the number of solicitors associated with or employed in each practice. Although this is not without its own difficulties, the data was checked to remove interstate and overseas offices of law practices. This data was aggregated and reported at the postcode level, and was then considered a suitable set of data for analysis at state-wide and regional levels. However, further explanation must be made of the relevance of interstate offices of law practices, out-of-state law practices, and the relative significance of using both the number of law practices and the number of solicitors as measures of access to legal services.

Interstate offices. A qualification must be made about the extent to which the spatial information given about law practices reflects the accessibility of legal

\footnotetext{
${ }^{41}$ This naturally follows the statutory meaning of a 'law practice': see Legal Profession Act 2004 (NSW) s 4; Legal Profession Act 2007 (Qld) sch 2. At times, a barrister (who must practise alone) is referred to in the legislation as a 'law practice': Legal Profession Act 2004 (NSW) ss 17, 310, 342, 344(2), 612, 623(3A); Legal Profession Act 2007 (Qld) ss 299(e), 309, 347(3)(a), 357(1), 736(1). Although in both states a barrister may be instructed directly (without briefing by a solicitor), this remains exceptional and a barrister is prohibited from undertaking most kinds of legal work, including conveyancing. The principal question of access to legal services is therefore taken to be access to a solicitor, a solicitors' firm, an ILP or an MDP: Cf New South Wales Bar Association, New South Wales Barristers' Rules (at 30 May 2008) rr 74-5, 80; Queensland Bar Association, Legal Profession (Barristers Rules) (at 1 July 2007) rr 78, 83.
} 
services. ${ }^{42}$ It was considered best to remove the data on interstate and overseas offices of law practices certified in each state as they were regarded as poor indicators of the accessibility of legal services in the relevant state. It also avoided any overlap of the data sets used for the two states and therefore it avoided counting solicitors twice. The data therefore necessarily centres on law practices which have principal solicitors certified as practising at offices in the relevant state, and any other in-state offices of those practices.

Interstate law practices. However, law practices with solicitors certified as practising in-state do not exhaust the opportunities that consumers of legal services - potential clients - have for accessing law practices. Put another way, law practices with solicitors certified in another state might also affect the availability of legal services to in-state residents. In both New South Wales and Queensland, lawyers certified for practice in any other state or territory (except South Australia) are entitled to practise in the state. ${ }^{43}$ In general, this qualification suggests a marginal improvement in access to legal services in both states but, so far as this comparison is concerned, probably more so for New South Wales residents than for Queenslanders. Although rights of interstate practice can be exercised by any lawyer anywhere in any other participating state, lawyers in border regions will inevitably be more reliable indicators of access to interstate legal services. The most populous border region in Australia is Coolangatta-Tweed Heads, but the larger urban area (the Gold Coast) and the higher number of law practices and solicitors are on the Queensland side. Further, New South Wales has more populous regions bordering Victoria (Albury-Wodonga, the Riverina) and the Australian Capital Territory (where New South Wales residents would often instruct lawyers in Canberra). Queensland's only populated Australian border is with New South Wales.

Indicators of Accessibility. The data adopts two different indicators of accessibility: the number of law practices, ${ }^{44}$ and the number of solicitors. In general, we suggest that the number of law practices is a more direct measure - from the consumer's side - of the formal range of choice available for accessing legal services. The number of solicitors is a better measure - from the supplier's side - of the actual capacity to provide legal services. So,

\footnotetext{
${ }^{42}$ For the exclusion of barristers from the question of access to legal services, see ibid.

${ }^{43}$ An 'Australian legal practitioner' may engage in legal practice in either state. This means an Australian lawyer who holds 'a current local practising certificate or a current interstate practising certificate'. South Australia does not yet participate in the reciprocal arrangements for this scheme. See Legal Profession Act 2004 (NSW) ss 6(1), 14(1); Legal Profession Act 2007 (Qld) ss 6(1), 24(1).

${ }^{44}$ For the definition of 'law practice', see above $\mathrm{n} 41$.
} 
consumers may have the choice of four practices in a regional town, and that choice remains only four whether each practice comprises only one or as many as five solicitors. However, in the absence of any question of conflicting duties, the practice that has five solicitors is much more likely to be in a position to accept a given consumer's instructions than the sole-solicitor practice is.

So far as measuring the accessibility of legal services goes, we have therefore used indicators that represent both consumer choice and capacity to provide legal services. While there are no empirical justifications for preferring one measure or the other as the more significant indicator of access to legal services, in general we assume that the number of solicitors would be a marginally better indication, at the very least, of the availability of legal services. True, the practice must be available to the consumer before the question of its capacity to do the work could even arise, and that could suggest that the number of law practices is a better indicator of accessibility. Small law practices (which predominate in regional and remote areas in both states) should not generally be acting for more than one of the parties in litigation, financing, conveyancing or, indeed, any other transactional work. ${ }^{45}$ The practice should not be accepting instructions if, by reason of potentially conflicting duties, its representation is not formally available to the consumer. Furthermore, there are good reasons to suggest that the possibility of conflicts between personal interests and duties to clients is more pronounced in regional and remote areas than it is in metropolitan settings. ${ }^{46}$ However, the spatial analysis undertaken by Economides and Blacksell on access to legal services in rural England and Wales used the number of solicitors as a measure of access to legal services. ${ }^{47}$ Further, we have two reservations about relying too strongly on the law practice as the better measure of the availability of legal services to consumers. The first is that formal access to a practice is meaningless if the lack of resources in the practice means it cannot provide legal services to a given consumer. The second is that it is possible that 'round-robin' consumer behaviour might see the greater capacity of

\footnotetext{
${ }^{45}$ See generally, G E Dal Pont, Lawyers' Professional Responsibility (Thomson Reuters, $4^{\text {th }}$ ed, 2010) 175-82.

${ }^{46}$ Landon's studies of rural lawyers in Missouri established the deeper social connections that rural lawyers have with people in their communities, and the higher incidence of multiplex relationships (not just established by the lawyer-client retainer) in rural practice. This compounds the possibility of personal conflicts: see Donald D Landon, Country Lawyers: the Impact of Context on Professional Practice (Praeger, 1990) 130, 138, 140, 143. There are no comparable studies for Australia, but the possibility of a similar dynamic in regional and remote areas of New South Wales and Queensland should be conceded.

${ }^{47}$ Kim Economides and Mark Blacksell, 'Access to Justice in Rural Britain: Final Report' (1987) 16 Anglo-American Law Review 353, 356-9.
} 
multi-solicitor practices to provide legal services effectively translate into improved consumer choice for legal services. If law practices, confronted with potential conflicts, refer work to other practices, and equally receive referrals from other practices that are confronting potential conflicts, ${ }^{48}$ then the law practice itself is less significant as a measure of actual access to legal services. As a result, we think it safer to prefer the number of solicitors as a measure of access to legal services: that is, three two-solicitor practices mean better legal service provision in a community than four sole practitioners. The capacity to provide the service seems to be, at the very least, a slightly better measure of access than the number of law practices. ${ }^{49}$

Whole State Comparisons. Table 1 summarises the state-wide information on law practices. It gives the number of law practices, the number of solicitors, the number of solicitors in the largest law practice and the median law practice size in each state.

Table 1: Law Practices: Whole State Comparisons

\begin{tabular}{|l|l|l|}
\hline State & New South Wales & Queensland \\
\hline Total Law Practices & 5652 & 1335 \\
\hline Total Solicitors & 20543 & 5824 \\
\hline $\begin{array}{l}\text { Largest Law Practice } \\
\text { (Number of Solicitors) }\end{array}$ & 516 & 158 \\
\hline $\begin{array}{l}\text { Median Law Practice } \\
\text { Size (Number of } \\
\text { Solicitors) }\end{array}$ & 1 & 2 \\
\hline
\end{tabular}

\section{Census Data}

Australian Bureau of Statistics (ABS) data was sourced to provide the postcode districts for both New South Wales and Queensland that were based on the 2006 census collection boundaries. The 2006 census data was also used to determine the total population for each postcode district. This formed the

\footnotetext{
${ }^{48}$ For referral practices in rural Missouri, see Landon, above n 46, 138, 143.

49 The number of solicitors may be even a significantly better measure of access to legal services than the number of law practices. In the absence of any information on how reliably these variables measure access to legal services, we have simply made the most conservative assumption.
} 
basis of calculations of the density of law practices and solicitors across both states.

\section{Accessibility/Remoteness Index of Australia}

The Accessibility/Remoteness Index of Australia (ARIA) was also incorporated into the spatial analysis. ARIA is a formal measure of the ease of access to fundamental services and, therefore, also of the remoteness of a given area from these services. Government and business decision makers continue to be challenged to understand and appreciate the difficulties faced by Australians living in regional and remote areas when accessing services that most other Australians take for granted. As the gap between services in the cities and those in the bush began to widen, governments, in particular, tried to understand more clearly the nature of 'remoteness' and hence improve the targeting of government services and programs. Various approaches to measuring remoteness across Australia have been investigated and trialled. These have included the Index of Remoteness in $1983 ;{ }^{50}$ the Rural, Remote and Metropolitan Areas classification in 1994; ${ }^{51}$ and the Griffith Service Access Frame. ${ }^{52}$ Although these approaches provided an improved understanding of the varying dimensions of remoteness and accessibility, they also carried a number of limitations which restricted their wider use. This prompted government service delivery agencies to find a more comprehensive and defensible index.

In 1996, the National Key Centre for Social Applications of Geographical Information Systems was commissioned to assist with a review of the Australian Standard Geographical Classification, which to that point had been widely used by the ABS. In particular, the review investigated the use of GIS to measure remoteness in a more objective and comprehensive way. ARIA

${ }^{50} \mathrm{H}$ W Faulkner and S French, 'Geographical Remoteness: Conceptual and Measurement Problems' (Reference Paper No 54, Bureau of Transport Economics, 1983).

${ }^{51}$ An index created by the then Department of Primary Industries and Energy and the Department of Human Services and Health. The classification has been criticised for anomalies due to population bias and its granularity, which often failed to reflect the remoteness of an area.

${ }^{52}$ Dennis A Griffith, 'The Griffith Service Access Frame: A Practical Model for Quantifying Access to Services, Developing Education Profiles and Measuring Government Policy Outcomes in Australia's Service Access Disadvantaged Areas' (Paper presented at the Northern Territory Institute of Educational Research Symposium, Darwin, 22-23 May 1998). 
was the result of a comprehensive methodology that combined road distances, geographic location and services centre information to define remoteness and access across the Australian continent.

A core component of the ARIA approach to accessibility and remoteness was the adoption of the ABS defined 'urban centres' which were used to categorise four levels of 'service centres' capable of providing basic services. It was assumed by the ARIA developers, and then further confirmed by their analyses, that there was a clear correlation between population size and the availability of public and commercial services. This relationship was most particularly evident in the health and education sectors, where relevant services (major hospitals and post-secondary educational institutions) were only available in cities with a large population base.$^{53}$ This relationship was also evident with other services. However, the necessary correlation was that, as the size of the service centre decreased, both the number and range of services also decreased but, as might be expected, according to no regular pattern. It remains impossible to make any certain prediction that a particular category of service centre will carry a particular kind of service.

In the development of ARIA, over 11000 urban centres across Australia were analysed and grouped into four service categories according to population $(\mathrm{N})$ :
A: $\mathrm{N} \geq 250000$
B: $\mathrm{N}=48000-249999$
C: $\mathrm{N}=18000-47999$
D: $\mathrm{N}=5000-17999$

53 Lyle Dunne, Errol Bamford and Danielle Taylor, 'Quantifying Remoteness - A GIS Approach' (Paper presented at the $11^{\text {th }}$ Annual Colloquium of the Spatial Information Research Centre, University of Otago, Dunedin, 13-15 December, 1999). 
Distance is the other main component in the calculation of the ARIA value for a particular locality. Road distances from the locality to the nearest service centre in each of the four categories are computed and assigned a value between 0 and 3.0, where 3.0 indicates a significant lack of accessibility to a particular category of service centre. For example, a locality with close access to a highly populated category A centre will receive a rating for that category, but because the services in this category are assumed to be already available in the smaller populated categories, the calculation of the distance to the other centres will have no further numerical impact on the calculation of the index. However, a locality that is very remote will be allocated a maximum value of 3.0 for each category starting from category A until it identifies a service centre where it is close enough to get a value that is less than 3.0. For example, the results from the calculation for a remote locality may yield values 3.0 for category A, 3.0 for category B, 3.0 for category $C$ and 1.6 for category D. These values are then aggregated to get the final ARIA value: ie, ARIA $=3.0+3.0+3.0+1.6=10.6$.

The calculated ARIA values will therefore range from 0 to 12 , and are then grouped into five categories. These give classifications of different categories of geographic areas in Australia as follows:

1. Highly or Very Accessible (ARIA score 0-1.8). These areas have relatively unrestricted access to a wide range of goods and services and opportunities for social interaction.

2. Accessible (ARIA score 1.8-3.5). These areas experience some restrictions on accessibility to some goods and services, and on opportunities for social interaction.

3. Moderately Accessible (ARIA score 3.5-5.8). These areas have significantly restricted accessibility to some goods and services, and to opportunities for social interaction.

4. Remote (ARIA score 5.8-9.1). These areas have very restricted accessibility to goods and services, and to opportunities for social interaction.

5. Very Remote (ARIA score 9.1-12). These areas have very little access to goods and services and to opportunities for social interaction. 


\section{Diagram 1: Accessibility/Remoteness Index for Australia - Classification for New South Wales and Queensland}

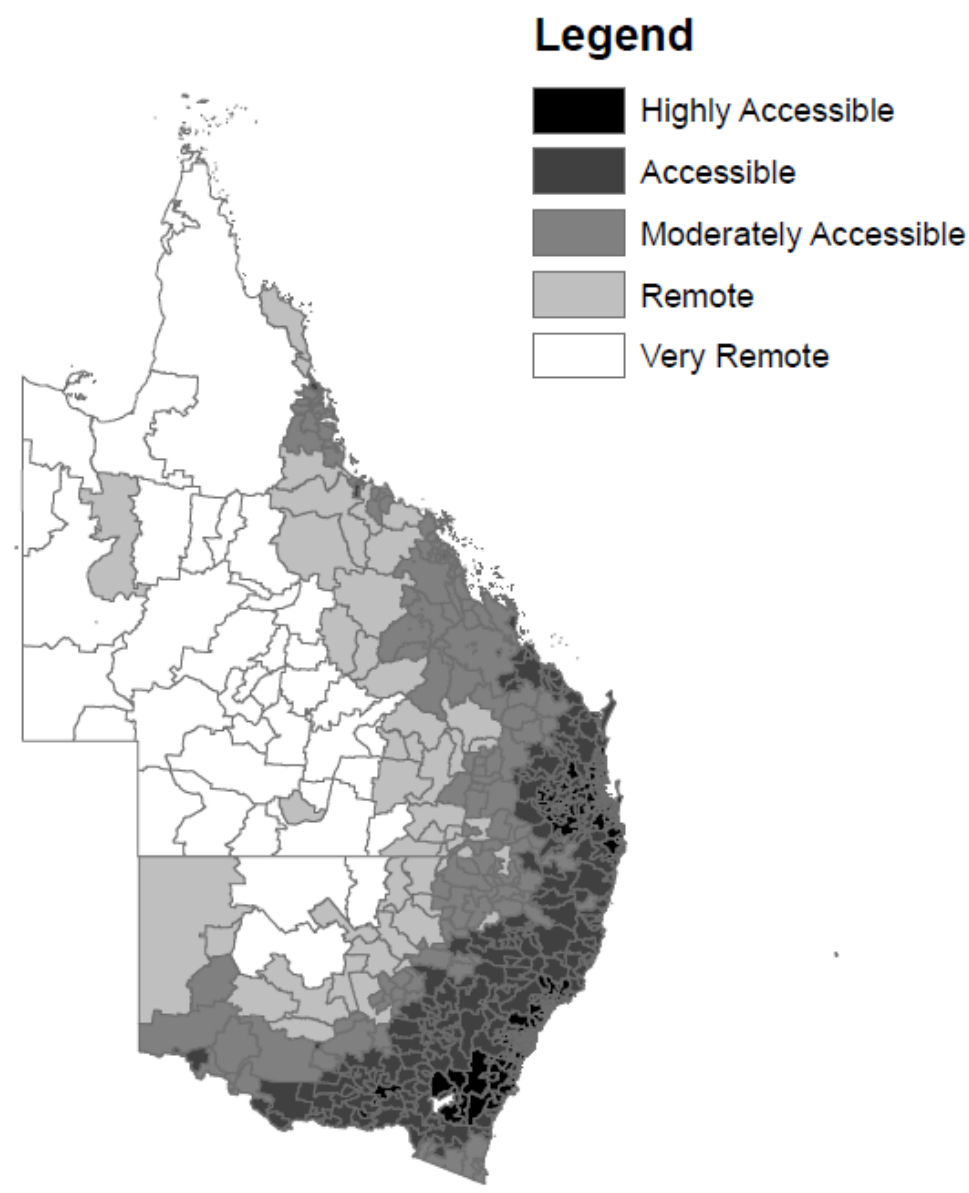

Any classification other than 'very accessible' means that, in terms of access to services, the area can be regarded as regional or remote. ${ }^{54}$ Diagram 1 gives the ARIA classification of geographic areas for both New South Wales and Queensland. The large very remote areas across mid-western New South Wales, western Queensland and Cape York Peninsula are clearly evident.

\footnotetext{
${ }^{54}$ ARIA scores $0.2-2.3$ can generally be regarded as 'Inner Regional', and 2.3-5.8 as 'Outer Regional'.
} 
There is only a small proportion of the western area in both states that has better access to services, and is naturally proximate to population centres such as Broken Hill (accessible) in New South Wales and Mount Isa (remote) in Queensland.

Like the other indices that have been developed to measure remoteness in Australia, ARIA is not a perfect measure, and the numerical value of the index should be used only as a guide for assessing remoteness. In some instances, other information and measures may need to be incorporated into the analysis in order that we can gain a more accurate insight into a particular community or location's access to services in the geographic area. However, for the purpose of developing a method of comparing localities that enjoy similar access to services, it was considered in this analysis that the ARIA classification of a locality would be a suitable means of correlating localities in one state with localities in the other according to their regionality or remoteness.

The cartographic presentation of the general accessibility of services across the two states in Diagram 1 can also be analysed and presented purely in terms of area by the charts in Diagrams 2 and 3. These show that approximately 61 per cent of New South Wales is classified as being accessible (very accessible, accessible or moderately accessible) while the remaining 39 per cent falls under the remote or very remote classification. ${ }^{55}$

\footnotetext{
${ }^{55}$ See Diagram 2 below.
} 
Diagram 2: Accessibility/Remoteness of New South Wales by Area

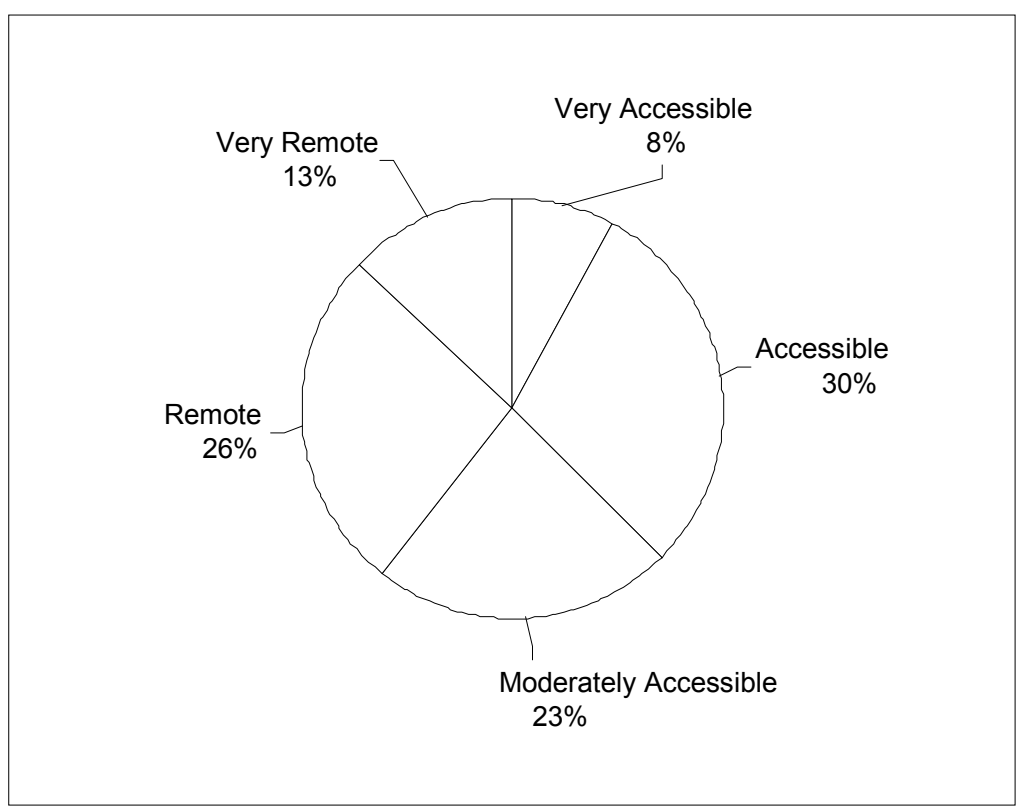

In comparison, large expanses of Queensland are classified as having poor access to services and are remote or very remote. ${ }^{56}$ Approximately 82 per cent of the area of Queensland falls into these two classifications, with the remaining 18 per cent classified as accessible in some degree. ${ }^{57}$

\footnotetext{
${ }^{56}$ See Diagram 3 below.

${ }^{57}$ Ibid.
} 


\section{Diagram 3: Accessibility/Remoteness of Queensland by Area}

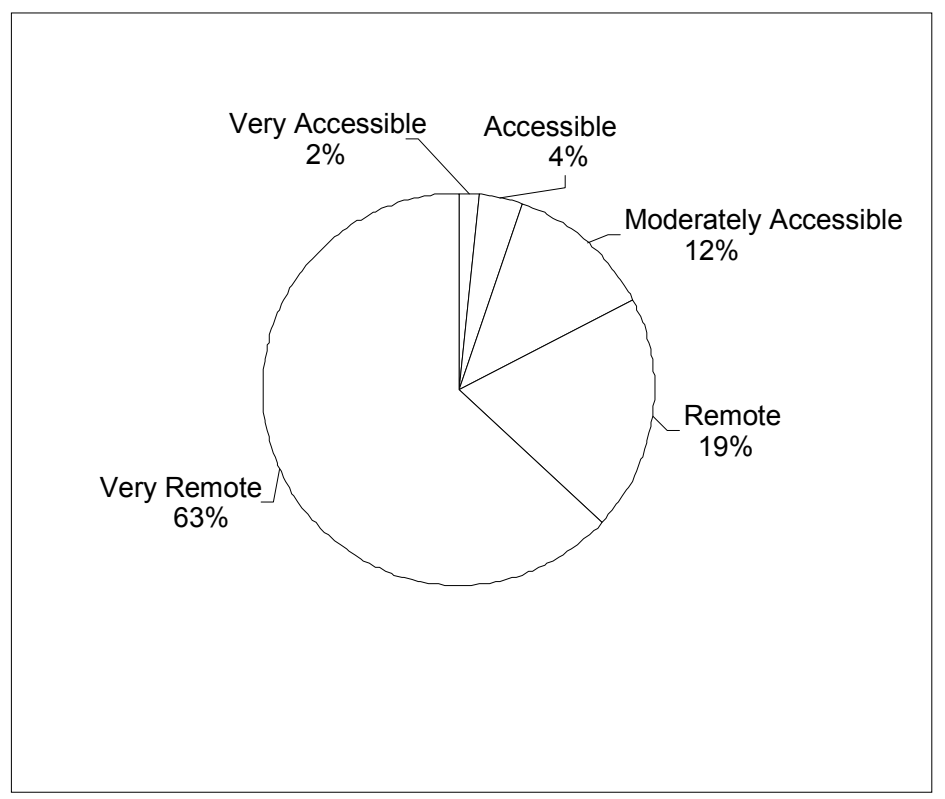

The percentages above serve to highlight the vast expanses of land, particularly in western and northern Queensland, that are considered to be very remote and to be lacking access to commonly available services. While these areas cover a significant portion of the state, they are also generally sparsely populated. Although providing a useful spatial comparison of remoteness and accessibility for each state, they therefore do not reflect the need or demand for legal services in these regions. In this regard, population data at a postcode level generally provides a suitable mechanism to explore the density of law practices and solicitors, and enable a comparative analysis across the two states.

\section{Comparative Analysis of Law Practices and Solicitors}

Using the underlying information and data on law practices in each state, and the ABS's 2006 census data, an initial comparison was undertaken of the density of both law practices and solicitors. This is illustrated in Diagram 4. While there are over four times as many law practices in New South Wales (5652) as there are in Queensland (1335), when population is taken into 
account the ratio becomes closer to 2.5 times the number of law practices per capita in New South Wales compared with Queensland.

\section{Diagram 4: Density of Law Practices - Whole State Comparison}

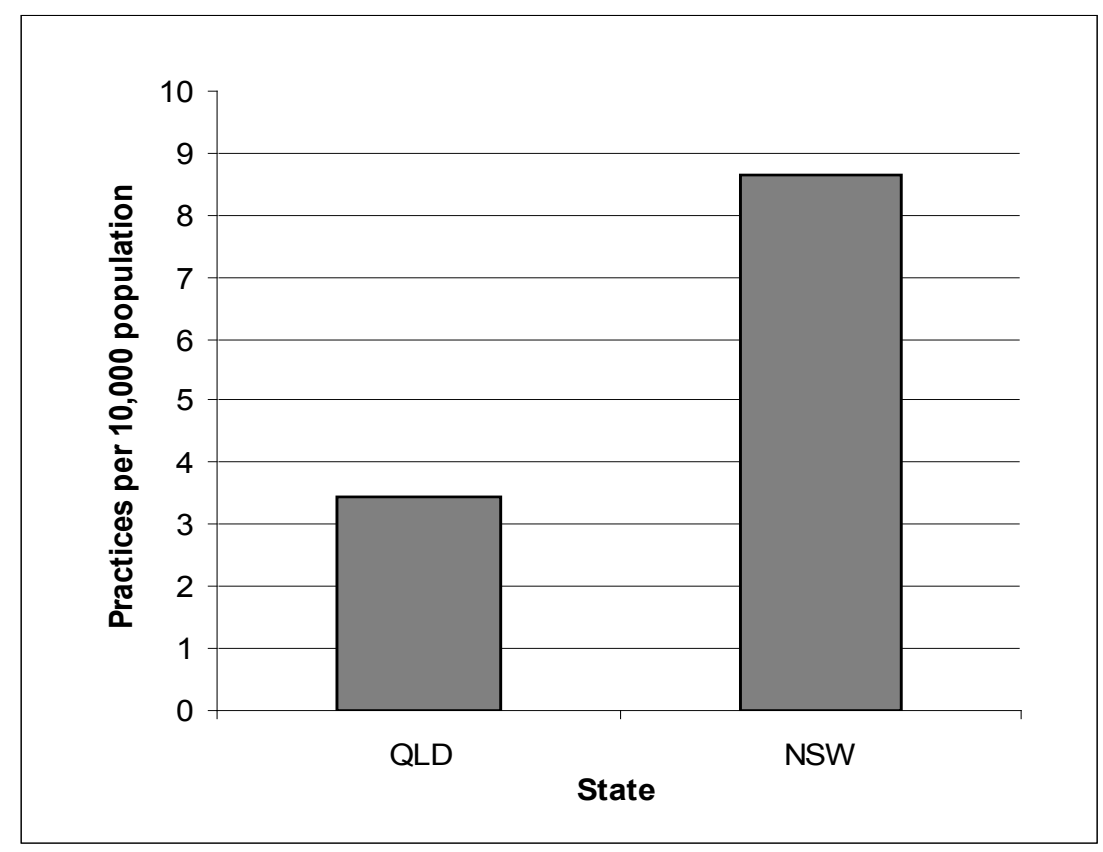

The density of law practices in each state is also examined in the context of law practice size and structure. Both states have a high number and proportion of practices comprising five or fewer solicitors: Queensland at around 85 per cent, and New South Wales at 92 per cent. This higher figure for New South Wales is reinforced by the median law practice size: just one solicitor in each practice. In other words, in New South Wales the most common law practice is a sole principal solicitor (with no employed solicitors) or an ILP comprising just one solicitor (the director). For Queensland, the most common law practice size is two solicitors.

When the total number of solicitors across each state is examined as a proportion of the state population, the difference between New South Wales and Queensland narrows, but remains significant. The number of solicitors per 10000 people in New South Wales is around 31, while the Queensland figures sit at around 15 solicitors per 10000 people. ${ }^{58}$ Again, in rough figures,

\footnotetext{
${ }^{58}$ See Table 4 and Diagram 5 below.
} 
this amounts to one solicitor for every 318 people in New South Wales as opposed to one for every 668 in Queensland. ${ }^{59}$

\section{Diagram 5: Solicitors per 10000 Population - Whole State Comparison}

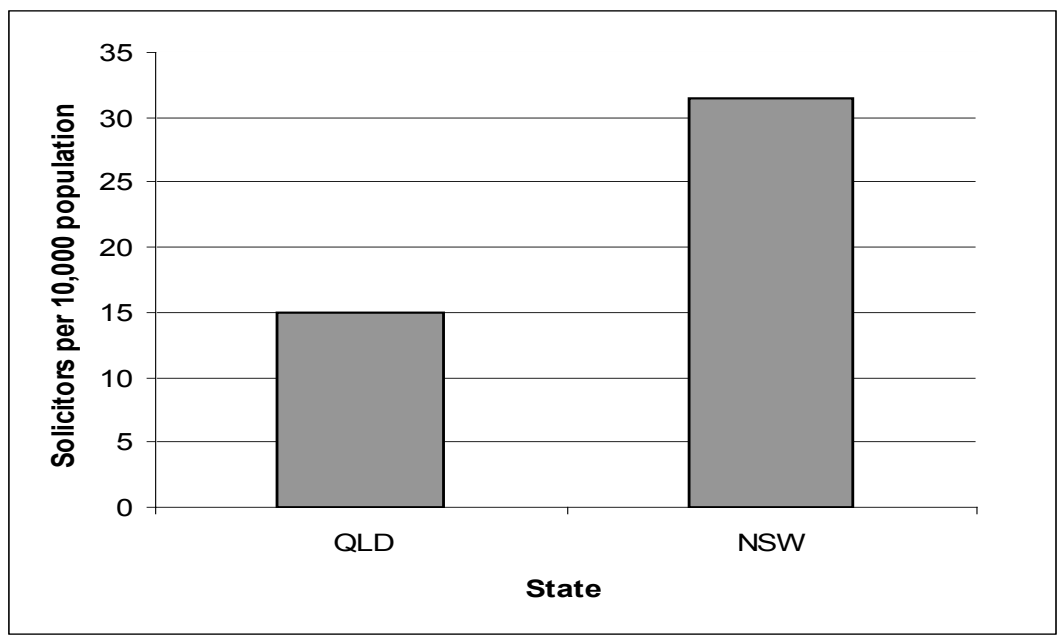

Using ARIA and postcode data, it is then possible to compare the apparent accessibility of legal services in each state. A number of observations can be made. First, the trends for access to both law practices ${ }^{60}$ and solicitors ${ }^{61}$ in general follow ARIA classifications of accessibility or remoteness in each state. In other words, generally in both states the more remote an area is according to its ARIA classification: (1) the fewer the number of law practices and solicitors there are per capita; and (2) the greater the population per law practice or solicitor. ${ }^{62}$

\footnotetext{
${ }^{59}$ See Table 5.

${ }^{60}$ See Tables 2 and 3 above.

${ }^{61}$ See Tables 4 and 5 above.

${ }^{62}$ There are two exceptions in the trend. In New South Wales, there are more law practices (but fewer solicitors) per capita in the remote classification than in the moderately accessible classification: Table 2. This is due to an aberration caused by the use of postcodes for the analysis. Specifically, the inclusion of Broken Hill (which is, as a city, classified as 'accessible') in a postcode district (2880) classified as 'remote' creates this distortion. See below $\mathrm{n} 64$ and associated text. In Queensland, there are more law practices and solicitors per capita in the 'very remote' classification than in the 'remote': Tables 2 and 4 . The numbers in both 'remote' and 'very remote' areas are small so, even though the numerical proportions seem to disturb the trend, they do not affect this general observation.
} 
Table 2: Law Practices per 10000 Population

\begin{tabular}{|l|c|c|}
\hline \multicolumn{1}{|c|}{$\begin{array}{c}\text { ARIA } \\
\text { Classification }\end{array}$} & New South Wales & Queensland \\
\hline Very Accessible & 9.70 & 3.99 \\
\hline Accessible & 3.50 & 2.37 \\
\hline $\begin{array}{l}\text { Moderately } \\
\text { Accessible }\end{array}$ & 2.90 & 1.53 \\
\hline Remote & 3.03 & 1.09 \\
\hline Very Remote & 1.04 & 1.32 \\
\hline Whole State & 8.64 & 3.43 \\
\hline
\end{tabular}

Table 3: Population per Law Practice

\begin{tabular}{|l|c|c|c|}
\hline ARIA Classification & New South Wales & Queensland & $\begin{array}{c}\text { Ratio } \\
\text { QId/NSW }\end{array}$ \\
\hline Very Accessible & 1031 & 2505 & 2.43 \\
\hline Accessible & 2859 & 4217 & 1.47 \\
\hline $\begin{array}{l}\text { Moderately } \\
\text { Accessible }\end{array}$ & 3445 & 6517 & 1.89 \\
\hline Remote & 3302 & 9178 & 2.78 \\
\hline Very Remote & 9590 & 7579 & 0.79 \\
\hline Whole State & 1157 & 2915 & 2.52 \\
\hline
\end{tabular}

Table 4: Solicitors per 10000 Population

\begin{tabular}{|l|c|c|}
\hline \multicolumn{1}{|c|}{ ARIA Classification } & New South Wales & Queensland \\
\hline Very Accessible & 36.13 & 18.01 \\
\hline Accessible & 8.30 & 8.96 \\
\hline Moderately Accessible & 6.00 & 6.05 \\
\hline Remote & 5.41 & 1.82 \\
\hline Very Remote & 2.06 & 1.98 \\
\hline Whole State & 31.42 & 14.96 \\
\hline
\end{tabular}


Table 5: Population per Solicitor

\begin{tabular}{|l|c|c|c|}
\hline ARIA Classification & New South Wales & Queensland & $\begin{array}{c}\text { Ratio } \\
\text { QId/NSW }\end{array}$ \\
\hline Very Accessible & 277 & 555 & 2.00 \\
\hline Accessible & 1204 & 1116 & 0.93 \\
\hline & & & \\
Moderately Accessible & 1666 & 1654 & 0.99 \\
\hline Remote & 1849 & 5507 & 2.98 \\
\hline Very Remote & 4795 & 5052 & 1.05 \\
\hline Whole State & 318 & 668 & 2.10 \\
\hline
\end{tabular}

Secondly, the New South Wales legal profession displays a stronger metrocentric quality than the Queensland profession does. Urban or very accessible areas of New South Wales have a high density of law practices and solicitors when compared with: (1) other parts of New South Wales; and (2) all (including very accessible) areas of Queensland. Indeed, the very accessible areas of New South Wales have 2.5 times the number of law practices and over four times the number of solicitors per capita than even accessible areas of the state, whereas in Queensland very accessible areas have only 1.7 times the number of law practices and twice the number of solicitors per capita as accessible areas. ${ }^{63}$ This confirms the well-known status of Sydney as the centre of legal business in Australia, in that it is: the location for the head office of many large, national practices; the Australian office of international practices; the busiest litigation centre in the Australasia-Pacific region; and Australia's largest commercial centre. It also suggests that, despite its rapid population and economic growth, Brisbane retains its branch-office status for national law practices. Accordingly, although New South Wales residents seem to have significantly better access to legal services than Queenslanders do when we consider each state as a whole, this is largely attributable to the concentration of law practices and solicitors in very accessible areas of New South Wales, and especially in Sydney.

Thirdly, overall the two states compare differently when the availability of legal services is measured by law practices and solicitors.

\footnotetext{
${ }^{63}$ See Tables $2-5$.
} 
Diagram 6: Distribution of Solicitors across New South Wales and Queensland

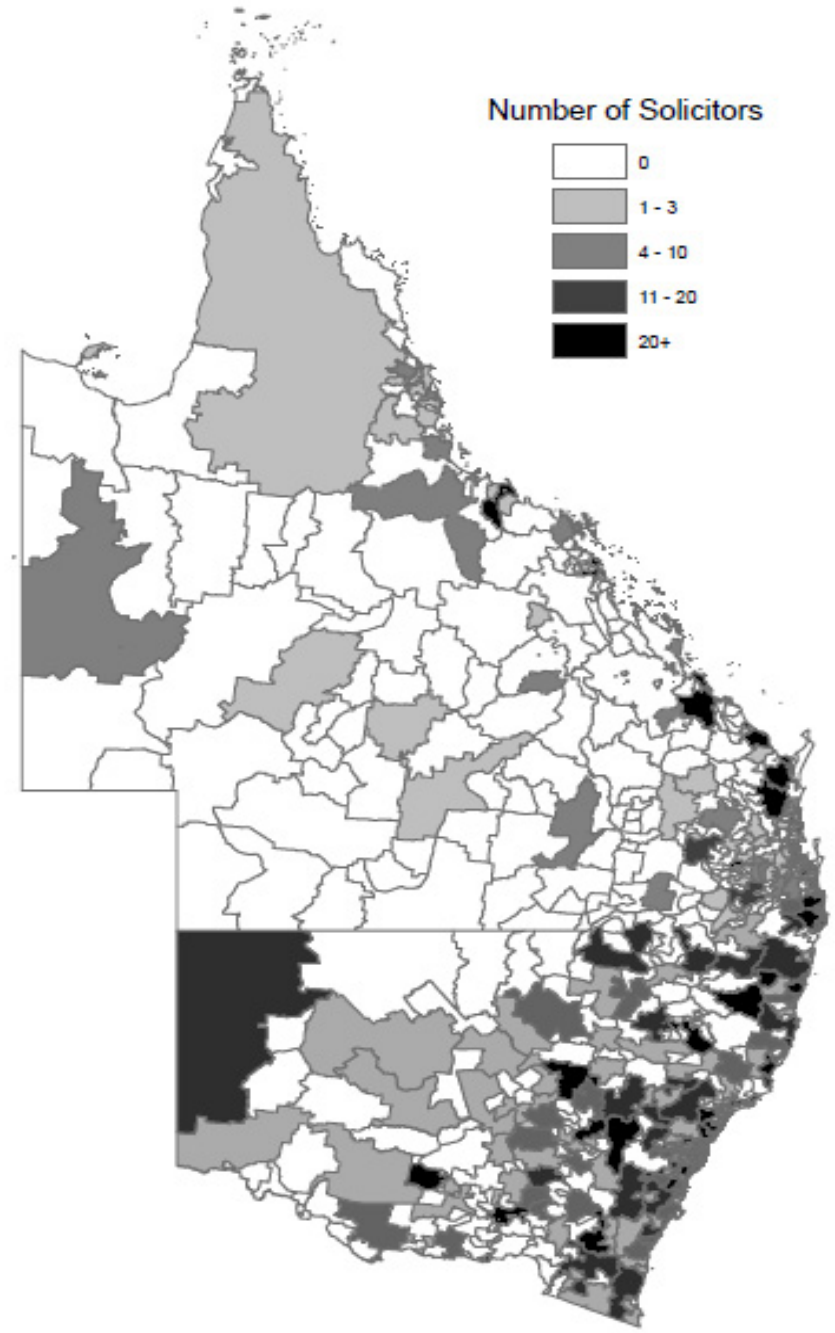

In general, in all regional and remote areas, New South Wales has a significantly greater number of law practices per capita than Queensland has. However, this trend is largely removed or smoothed when the number of solicitors per capita is compared. There is one exception. In the ARIA remote areas, New South Wales has a significantly higher density of solicitors, around three times the ratio of Queensland. This is an aberration caused by the 
sorting of data by reference to postcode district. It is directly attributable to the proximity of these solicitors to Broken Hill which, despite belonging to a postcode district that is classified as remote, is as a city classified as accessible. The number of solicitors in Broken Hill is compatible with other areas classified as accessible. ${ }^{64}$

Fourthly, the comparative data do not necessarily show that the availability of legal services in the bush is adequate in either state, but the inadequacy is more particularly evident in Queensland. Economides and Blacksell's analysis of access to legal services in rural England and Wales marked the most poorly served areas as those with at least 3334 people per solicitor, and that was in $1987 .{ }^{65}$ In both New South Wales and Queensland 'very remote' areas exceeded this ratio in 2008, but in Queensland 'remote' areas did so as well. The provision of legal services across the larger distances, and more sparsely populated areas, evidently creates difficulties for service provision in Australia, and especially Queensland - difficulties which are not experienced in England and Wales. ${ }^{66}$

Furthermore, Economides and Blacksell noted that ' $[\mathrm{t}]$ he districts where provision is worst are generally those with rapidly expanding suburban populations on the fringes of the major centres of population. ${ }^{67}$ These were mostly adjacent to districts that were amongst the best served by solicitors in England and Wales. ${ }^{68}$ Diagram 6 illustrates a similar phenomenon in the Australian distributions. In New South Wales, regional cities like Armidale, Tamworth, Dubbo, Bathurst and Griffith are amongst the best served areas for solicitors, but adjoin areas that have no solicitors whatsoever. The same pattern occurs around Maryborough-Hervey Bay, Bundaberg, Rockhampton and Townsville on the Queensland coast. However, the difference is that, in England and Wales, almost all of the poorly served districts were adjacent to the best served districts, whereas in New South Wales and Queensland, until Broken Hill or Mount Isa is reached, the westward trend of poorer legal service provision is generally unbroken.

\footnotetext{
${ }^{64}$ See above $n 62$.

${ }^{65}$ Economides and Blacksell, above n 47, 357.

${ }^{66}$ The poorest served district in Economides and Blacksell's study had 76610 people per solicitor: ibid. This is a larger population than was resident in the whole of the very remote areas of New South Wales or Queensland.

${ }^{67}$ Economides and Blacksell, above n 47, 358.

${ }^{68}$ Ibid 357.
} 


\section{CONCLUSIONS}

\section{A General Conclusions}

So far as the accessibility of general services is concerned, there is evidently a significantly greater challenge for Queensland than New South Wales, with higher proportions of the former state being areas that are classified as either remote or very remote, ${ }^{69}$ and with a larger population being without adequate services. The data on the accessibility of legal services nevertheless suggests that legal service provision remains inadequate in the New South Wales bush, as well as in similar areas of Queensland. ${ }^{70}$ That said, legal service provision in regional, rural and remote areas of New South Wales appears to be equal or, perhaps, even marginally better than it is in Queensland. Legal service provision measured by the number of solicitors is similar in regional and remote areas of New South Wales and Queensland that enjoy relatively similar levels of access to other general government and business services. ${ }^{71}$ The rough figure of one solicitor for every 318 people in New South Wales (as compared with one for every 668 in Queensland) is therefore explained by the volume of legal work or the national concentration of legal business in Sydney. However, the difference between metropolitan legal service provision on the one hand, and regional and remote provision on the other, is much greater in New South Wales than it is in Queensland. The better access to legal services overall in New South Wales therefore rests on a stronger metrocentric profile for its legal profession, and does not translate into significantly better legal service provision in the bush. While this comparison reinforces the conclusion of the Rural, Regional and Remote Areas Report that legal service provision in the Queensland bush is poor, the roughly comparable levels of legal service provision in the accessible, moderately accessible, remote and very remote areas of both states may cast doubt on the implication that there is greater cause for concern about access to lawyers in the Queensland bush than in New South Wales. ${ }^{72}$

It is possible, however, that there is marginally better access to legal services in the New South Wales bush than in comparable parts of Queensland. First, despite comparable number of solicitors per capita in regional and remote areas of both states, there are significantly higher numbers of law practices

\footnotetext{
${ }^{69}$ See Diagrams 2 and 3 above.

${ }^{70}$ See above nn $65-66$ and associated text.

${ }^{71}$ See Tables 4 and 5 above.

${ }^{72}$ Law Council of Australia and Law Institute of Victoria, above n 1, 21.
} 
per capita in New South Wales. ${ }^{73}$ It is the stronger tendency of Queensland solicitors to practise in twos, and of New South Wales solicitors to practise alone, that sees this distinction emerge. ${ }^{74} \mathrm{We}$ have assumed that the better measure of access to law is the number of solicitors per capita. ${ }^{75}$ However, since the data on that measure for the two states is comparable, evidence of a higher density of law practices could be understood as resulting in better legal service provision in New South Wales. Secondly, we note that in the border regions of New South Wales access to legal services might also be better than this analysis indicates because of the availability of solicitors in southern Queensland, the Australian Capital Territory and northern Victoria. ${ }^{76}$ Its significance naturally depends on the extent to which consumers are willing to cross borders to have legal work undertaken, and that cannot at present be quantified.

\section{B The Conveyancing Claim}

The question then becomes, what are the implications of this data for the conveyancing reservation for solicitors in Queensland and, in particular, the bush lawyers argument given for it? There are two conclusions that can be drawn from the results. First, the introduction of non-lawyer conveyancing in New South Wales in 1993 under the Conveyancers Licensing Act 1992 (NSW) has not prevented that state from maintaining conditions that enable an equal or better provision of legal services - and therefore of access to law — than is the case in Queensland. ${ }^{77}$ The second conclusion is the other side of the same coin. The continued maintenance in Queensland of an exclusive reservation of conveyancing work for solicitors has not enabled that state to give better support for the provision of legal services than New South Wales has.

From these two conclusions, it then only becomes possible to draw inferences. In an analysis such as the present, it is never possible to control for all considerations that might affect the availability of legal services and, as a result, to isolate the effect that one consideration (like conveyancing protection) might have on the viability and incidence of solicitors' practices. However, there are two assumptions that it seems reasonable to make, and that exclude a number of considerations from this analysis. First, it is assumed

\footnotetext{
${ }^{73}$ See Tables 2 and 3 above.

${ }^{74}$ See Table 1 above.

${ }^{75}$ See above nn $44-49$ and associated text.

${ }^{76}$ See above $\mathrm{n} 43$ and associated text.

${ }^{77}$ Despite Grant's forebodings: see above n 30, 453.
} 
that most issues raised in Mundy's research - family, lifestyle, professional development, gender, job demands and employment patterns and salary ${ }^{78}-$ would have relatively similar effects on legal service provision across the two states in areas of similar ARIA classification. Nevertheless, in the period since the Conveyancers Licensing Act 1992 (NSW), one of these 'social' considerations - education in a regional law school - has differed significantly between the two states. This must therefore be accounted for in this analysis. ${ }^{79}$ Secondly, the legal infrastructure regulating solicitors' fees in the period since the mid-1990s has been the same in both states. Competitionbased reforms saw agreed scales of fees - a form of price-fixing dismantled through the early 1990s and banned in both states in $1995 .{ }^{80}$ For conveyancing in particular, the evidence accepted by the National Competition Council is that solicitors' fees in Queensland are by national standards at competitive levels and, therefore, that profit margins for conveyancing in Queensland are unlikely to be more generous there than elsewhere as a result of either regulatory arrangements or conveyancing protection. ${ }^{81}$

With those assumptions in place, it is therefore likely that only three differences in legal and social infrastructure remain that could have any effect on the availability of legal services in the New South Wales and Queensland bush. The two differences in legal infrastructure are conveyancing protection and ILPs. Although ILPs became available to law practices in Queensland from mid-2007, ${ }^{82}$ they were available in their present form in New South Wales from mid-2001. ${ }^{83}$ ILPs give advantages in limited liability, capital financing, income distribution and tax deferral that are not available to traditional unincorporated law practices and might be thought to have been more supportive of the sustainability of law practices in New South Wales than was the case in Queensland between 2001 and 2007.

The third difference between the states in the period up to 1 July 2008 was the higher number of regional law schools in New South Wales. Mundy has noted the suggestion - and that is all it amounts to - that a graduate of a regional

\footnotetext{
${ }^{78}$ Mundy, above n 5, 12-16.

${ }^{79}$ Ibid 14.

${ }^{80}$ Competition Policy (Reform) Act 1995 (NSW); Competition Policy (Reform) Act 1995 (Qld). For Queensland, see Stephen Corones, 'Solicitors Subject to the Trade Practices Act' (1996) 16(6) Proctor 10-11; Lamb and Littrich, above n 33, 109.

${ }^{81}$ Conveyancing Reservation II, above n 29.

${ }^{82}$ Legal Profession Act 2007 (Qld) ss 109-161

${ }^{83}$ Legal Profession Amendment (Incorporated Legal Practices) Act 2000 (Q1d), commencing 1 July 2001. For the background to this development, see Dal Pont, above n 45, 455-6.
} 
law school is more likely to take up legal practice in the bush than is a graduate of a metropolitan law school. ${ }^{84}$ There were up to six law schools either in or proximate to regional, rural and remote areas of New South Wales in the 1990s and earlier 2000s ${ }^{85}$ whereas in Queensland there was one with two regional campuses. ${ }^{86}$ As yet, there is no empirical evidence that the presence of regional law schools helps to improve the density of law practices in the bush, although the Rural, Regional and Remote Areas Report did note that New South Wales and Queensland had the highest, and similar, proportions of bush lawyers who had studied by distance education. ${ }^{87}$ Still, the supporting effect of regional law schools may be doubted for two reasons. First, during the same period, the supply of law graduates from universities in both states significantly exceeded the demand for employment in the private profession. The second, and related, reason is that there were in the 1990s higher proportions of law graduates per capita in Queensland than in New South Wales and the Australian Capital Territory (which can be expected largely to feed New South Wales with its law graduates). Although Queensland had fewer regional law schools, law student numbers in its metropolitan universities were higher ${ }^{88}$ As a result, it is equally possible to suggest that, given the supply of law graduates in the period, the location of law schools in regional areas was of little or no consequence for recruiting solicitors for bush law practices.

The evidence given in this analysis therefore allows us to infer that, given that the equal or marginally better legal service provision in New South Wales holds for all ARIA classifications except the 'very remote', the provision of legal services in the New South Wales and Queensland bush is relatively unaffected by the two states' different legal and social infrastructure for

\footnotetext{
${ }^{84}$ Mundy, above n 5, 14.

${ }^{85}$ These are the law schools at the Universities of Newcastle, Wollongong and New England (Armidale), and Southern Cross University (Lismore). The Australian National University and the University of Canberra provide more graduates to New South Wales than to the Australian Capital Territory: cf ibid.

${ }^{86}$ James Cook University of North Queensland, where the law school has a presence in Townsville and Cairns. Regional law schools have since been established at the University of Southern Queensland (Toowoomba) in 2008, and Central Queensland University (Rockhampton) from 2011.

${ }^{87}$ Law Council of Australia and Law Institute of Victoria, above n 1, 29.

${ }^{88}$ In 1994, there were 781 final year law students in Queensland and a total of 1051 in New South Wales and the Australian Capital Territory (a ratio of 1/1.3). In population, the ratio for Queensland to New South Wales and the Australian Capital Territory together was 1/2.3. In other words, there was a comparatively high number of final year law students in Queensland: Christopher Roper, Career Intentions of Australian Law Students (AGPS, 1995) 12; Lamb and Littrich, above n 34, 14-15.
} 
conveyancing protection, ILPs and regional law schools. It also suggests that the other social considerations identified in Mundy's research - family, lifestyle, professional development, gender, job demands and employment patterns and salary ${ }^{89}$ - are much more likely to be significant determinants of the provision of legal services than is the legal infrastructure for supporting law practices.

\section{Provisos}

Equally, it could be argued that, if conveyancing protection did provide support for bush law practices against competition from non-lawyer conveyancers, the effect of lowering barriers to entering New South Wales conveyancing markets was more than offset by the earlier introduction of ILPs, the larger number of regional law schools, or both. Evidently, a more coherent picture of the comparative impact of these three considerations could be gained by a longitudinal assessment of the effect that the introduction of non-lawyer conveyancing in New South Wales under the Conveyancers Licensing Act 1992 has had on legal service provision in regional and remote areas of the state. ${ }^{90}$ If parallel sets of data were available from $1993,{ }^{91}$ a much larger longitudinal analysis could be undertaken, and would improve assessments of the conclusions made above. In particular, the effect of the conveyancing reservation could be isolated more distinctively from the impact of ILPs and regional law schools if the ratios set out in Tables 3 and 5 were to show a declining trend from 1993. If the Queensland/New South Wales ratios of population per law practice and population per solicitor were to show a general decline, this would mean that, from the time that non-lawyer conveyancing was reintroduced in New South Wales, either: (1) improvements in legal service provision had been greater in Queensland than New South Wales; or (2) any decline in legal service provision had not been as pronounced in Queensland as in New South Wales. That, of course, would amount to stronger evidence that conveyancing protection had helped to support access to legal services. However, the surrounding evidence from other research is still compatible with the inference suggested earlier: ie, that legal infrastructure (including the conveyancing reservation) has not made

\footnotetext{
${ }^{89}$ Mundy, above n 5, 12-16.

${ }^{90}$ Cf Grant's forebodings: see above n 30, 453.

${ }^{91}$ They were not available for the present analysis. Although the Law Society of New South Wales has the necessary information from 1993, the Queensland Legal Services Commissioner only has information from 2004 (when the position was established). Any earlier information from Queensland is held by the Queensland Law Society, and was not available for this research. The Queensland Law Society has now agreed to provide the data for a longitudinal analysis from 1991: E-mail from Noela L'Estrange to Reid Mortensen, 21 October 2010.
} 
any measurable difference to the density of legal services in the bush. First, between 1996 and 2001 the level of legal service provision in most of regional and remote Queensland appears to have declined. ${ }^{92}$ Secondly, it appears that the availability of legal services in New South Wales has improved considerably since 1993. Although much of this availability was concentrated in Sydney, there was still in this period a 47 per cent increase in the number of solicitors in New South Wales law practices outside Sydney. ${ }^{93}$ The parallel data for Queensland as a whole is not yet available. ${ }^{94}$

In a related qualification, the data presented shows the status of New South Wales and Queensland solicitors' practices as of 1 July 2008 and, therefore, predates both the Global Financial Crisis (GFC) of 2008 and 2009 and the contraction of Australian property markets that came with it. Longitudinal data beyond 2008 should indicate the effect of the GFC on the provision of legal services, and it is expected that any shrinkage in conveyancing business would be detrimental to the viability of law practices in all ARIA classifications. Equally, we expect that any GFC-driven contraction of property markets is likely to have had an even greater negative impact on nonlawyer conveyancing businesses because, being without the more extensive service differentiation that is possible for law practices, the viability of conveyancing businesses is even more broadly exposed to a downturn in property markets. ${ }^{95}$

92 Jennifer Waterhouse and Neal Ryan, Retention of Professional Services in Regional Queensland: Preliminary Research Component - Report to the Regional Communities Engagements, Department of the premier and Cabinet (Queensland University of Technology, January 2004), 17-19. There were increases in the number of lawyers in only Brisbane, the Gold and Sunshine Coasts, Townsville and Cairns; and a very small increase in Toowoomba. These localities are all classified as ARIA either 'highly accessible' or 'accessible' (Townsville and Cairns): at 17.

${ }^{93}$ Grant reported that the ratio of population per solicitor in New South Wales in 1992 was 550, compared with 318 in 2008: see Grant, above n 30, 453, and Diagram 5. Mundy reports that, in 1993, there were 5788 solicitors practising in the Sydney CBD, 3328 in Sydney's suburbs, and 1925 in 'rural' areas. This increased in 2007 to, respectively, 11309 (a 95 per cent increase), 6220 (87 per cent) and 2822 (47 per cent). The higher proportionate increases in Sydney mean that, although there were significantly more solicitors in 'rural' New South Wales in 2007 than there were in 1993, the proportion of solicitors in 'rural' practice as compared with Sydney practice decreased from 16 per cent to 13 per cent: Mundy, above n 5,9.

${ }^{94}$ See above $\mathrm{n} 91$.

${ }^{95}$ Given the bush lawyers argument, it is ironic that law practices are probably in a better structural position to weather the GFC than non-lawyer conveyancers because solicitors' conveyancing practices can be cross-subsidised by work that is either counter-cyclical (such as debt recovery and insolvency) or less sensitive to general market conditions (such as general litigation or family law). 


\section{A Contrarian Argument}

Finally, we note that the data presented in this study might be used by some to elevate the bush lawyers conveyancing claim. Indeed, it is almost inevitable that it will be argued that, if access to legal services in Queensland is even marginally poorer than it is in New South Wales, then there is a heightened need to maintain the state's conveyancing reservation for solicitors. If, the 'contrarian' argument continues, regional and remote law practices were not to enjoy protection for their conveyancing business, then legal service provision in these parts of Queensland would degenerate even further.

In relation to the contrarian argument, we make three related points. First, the argument assumes that the removal of protectionist measures (like the conveyancing reservation) is necessarily detrimental to the businesses or practices that they protect. As already noted, this cannot be assumed. There are important economic assessments that support the argument that removing protection can help formerly protected businesses to improve their viability. ${ }^{96}$ Secondly, the contrarian argument is, again, just an assertion. The evidence presented in this spatial analysis establishes that, although New South Wales reactivated non-lawyer conveyancing in 1993, the provision of legal services in its regional and remote areas was, in 2008, equal to that in Queensland or marginally better, and significantly better across the state as a whole than it was in $1992 .{ }^{97}$ Thirdly, putting the other two points together, the contrarian argument is bootstrapping. It claims that protection is needed to support the viability of law practices because it assumes that protection supports the viability of practices. Indeed, the weakness of circularity in this argument is one that may also affect the general claim about bush lawyers and conveyancing protection itself.

\section{The Upshot}

This spatial analysis suggests that, when arguing its case for maintaining the reservation of conveyancing work for solicitors in Queensland, the Queensland Law Society still has no evidence to support the bush lawyers argument. The results of this analysis are not compatible with the suggestion that the conveyancing reservation helps to support regional, rural and remote area legal practice. If anything, this analysis is more compatible with the view that conveyancing protection and other forms of legal infrastructure are not as important for maintaining and improving the provision of legal services in the

\footnotetext{
${ }^{96}$ Productivity Commission, above $\mathrm{n} 31$.

${ }^{97}$ See above nn 69-74 and associated text; Mundy, above n 5, 9.
} 
bush as social considerations (such as family, lifestyle, professional development, gender, job demands and employment patterns and salary) are likely to be. ${ }^{98}$

It must be reiterated that this is not to say that there are no other reasons for maintaining the conveyancing reservation for solicitors in Queensland. Byrne and Mortensen's research suggests that, especially since the introduction of ILPs in Queensland, the most protective, cost-efficient arrangement for consumers of conveyancing services may well be the conveyancing reservation. ${ }^{99}$ This study merely suggests that there is yet no evidence that the bush lawyers argument is a valid justification for conveyancing protection.

The more serious concern remains the inadequate level of legal service provision in regional, rural and remote New South Wales and Queensland. The Law Council is legitimately concerned about the crisis in bush legal practice, and efforts must be taken to improve conditions for supporting legal practice outside metropolitan areas. ${ }^{100}$ Although this spatial analysis begins to collect evidence about the effect of the Queensland conveyancing reservation on bush practice, it also reinforces the more serious challenge for both state governments and both states' legal professions. Is there other legal and social infrastructure that could help give regional and remote Australians the access to law that metropolitan Australians take for granted?

\footnotetext{
${ }^{98}$ Mundy, above n 5, 12-16.

${ }^{99}$ Conveyancing Reservation I, above n 29; Conveyancing Reservation II, above n 29.

${ }^{100}$ Law Council of Australia and Law Institute of Victoria, above n 1, 9-10.
} 